https://doi.org/10.26593/jihi.v17i1.3488.77-96

\title{
Indonesia-Russia Strategic Partnership in Southeast Asia
}

\author{
Hendra Manurung ${ }^{1}$ and Arry Bainus ${ }^{2}$ \\ ${ }^{1}$ International Relations, Padjadjaran University, Indonesia, hendra19001@mail.unpad.ac.id \\ 2Professor of Security Studies, Padjadjaran University, Indonesia, arrybainus@unpad.ac.id
}

\begin{abstract}
This paper aims to elaborate Indonesia and Russia bilateral relations, which closer post March 2018, after both countries leaders in Moscow agree accelerating the draft of the new strategic partnership agreement. Both countries cooperation has been going on for 70 years, since 3 February 1950. Foreign Ministers Retno Marsudi and Sergey Lavrov signed a Plan of Consultation 2017 to 2019 pursued at bilateral interactions intensification. This paper uses a strategic partnership approach through descriptive research and a qualitative approach with literature study data sources from books, journals, research reports that support the search for the results of the analysis. Kremlin views Jakarta as regional influential power and able to become dominant regional actor in Southeast Asian. Based on historical relations that have existed for a long time, the strengthening of the Indonesia-Russia Comprehensive Strategic Partnership has produced various concrete achievements for the advancement of national development, which still need to be improved. Russia is Indonesia's trading partner in Eurasia, and one of the prospective foreign investors in Indonesia. This closeness is also marked by the increasing number of visits between the peoples of the two countries. This paper revealed, through Russia with ASEAN dialogue partnership, thus, a road map under working framework in strengthening closer political economic relations along with mutual benefits pursued by Jakarta and Moscow also should be implemented and proceed further by concrete policy implementation.
\end{abstract}

Keywords: Indonesia, Russia, bilateral relations, strategic partnership, Southeast Asia

\section{ABSTRAK}

Tulisan ini bertujuan untuk mengelaborasi hubungan bilateral Indonesia dan Rusia yang semakin dekat pasca Maret 2018, setelah kedua pemimpin negara sepakat mempercepat penyusunan perjanjian kemitraan strategis baru di Moskow. Kerjasama kedua negara telah berlangsung selama 70 tahun, sejak 3 Februari 2020. Menteri Luar Negeri Retno Marsudi dan Sergey Lavrov menandatangani Rencana Konsultasi 2017 hingga 2019, bertujuan intensifikasi interaksi bilateral. Tulisan ini menggunakan pendekatan kemitraan strategis melalui penelitian deskriptif dan pendekatan kualitatif dengan sumber data studi literatur dari buku, jurnal, laporan penelitian yang mendukung pencarian hasil akhir dari analisis. Kremlin mempersepsikan Jakarta masih menjadi kekuatan regional berpengaruh dan mampu menjadi aktor regional dominan di Asia Tenggara. Didasari hubungan sejarah yang telah terjalin sejak lama, penguatan Kemitraan Strategis Komprehensif Indonesia-Rusia selama ini telah menghasilkan berbagai capaian konkret bagi kemajuan pembangunan nasional, dan masih perlu disempurnakan. Rusia adalah mitra dagang Indonesia di kawasan Eurasia dan salah satu investor asing prospektif di Indonesia. Kedekatan ini juga ditandai dengan terus meningkatnya saling kunjung diantara masyarakat kedua negara. Tulisan ini menemukan, melalui kemitraan dialog Rusia dengan ASEAN, maka peta jalan di bawah kerangka kerja tersebut akan memperkuat hubungan politik-ekonomi yang lebih dekat serta saling menguntungkan yang juga diupayakan oleh Jakarta dan Moskow, turut harus dilaksanakan dan dilanjutkan lebih jauh melalui implementasi kebijakan konkrit.

Kata kunci: Indonesia, Rusia, hubungan bilateral, kemitraan strategis, Asia Tenggara 


\section{Introduction}

Almost nobody disputes that the end of the Cold War had a profound impact on the whole pattern of international security but, more than a decade after the transition, the character of the post-Cold War security order still remains hotly contested ${ }^{1}$. Thus, by seeking to limit external influences and by developing a regulatory framework for managing interstate relations, regional cooperation has made the crucial difference between the forces of conflict and harmony that lie at the core of the international relations of Southeast Asia.

After 75 years of Indonesian independence, there has been no significant change in the paradigm shift of the national defense strategy. Based on Presidential Regulation Number 41/2010, Indonesian defense paradigm is one of the functions of state government carried out through the people's defense system universe, aims to safeguard and protect national sovereignty, territorial integrity as well as the safety of the entire nation from all forms of threats ${ }^{2}$. Indonesian national defense development refers to a comprehensive management system, which specific policy is necessary for various related aspects. Indonesia's defense policy is flexible and adaptive which is manifested in the direction and objectives of the central government's policies ${ }^{3}$. Indonesia's existing national security situation is very influential for the strategic interests of other

\footnotetext{
${ }^{1}$ Barry Buzan and Ole Wæver. 2003. Regions and Powers the Structure of International Security. University of Cambridge Press, UK, p. 31

${ }^{2}$ Kementerian Pertahanan Republik Indonesia. (2010, June 17). Peraturan Presiden Republik Indonesia Nomor 41 Tahun 2010 Tentang Kebijakan Umum Pertahanan Negara 2010-2014. Retrieved 10 December 2020.

https://www.kemhan.go.id/strahan/2016/09/29/perpres-no41-tahun-2010-tentang-kebijakan-umum-pertahanannegara-tahun-20102014.html.

${ }^{3}$ Kementerian Pertahanan Republik Indonesia. (2017, May

2). Kebijakan Pertahanan Negara 2018. Retrieved 10 January 2021. https://www.kemhan.go.id/2018/02/14/kebijakanpertahanan-negara-tahun-2018.html.
}

countries and directed at efforts to achieve national security stability that is conducive to regional and global stability ${ }^{4}$.

Figure Indonesia's Strategic Interest in

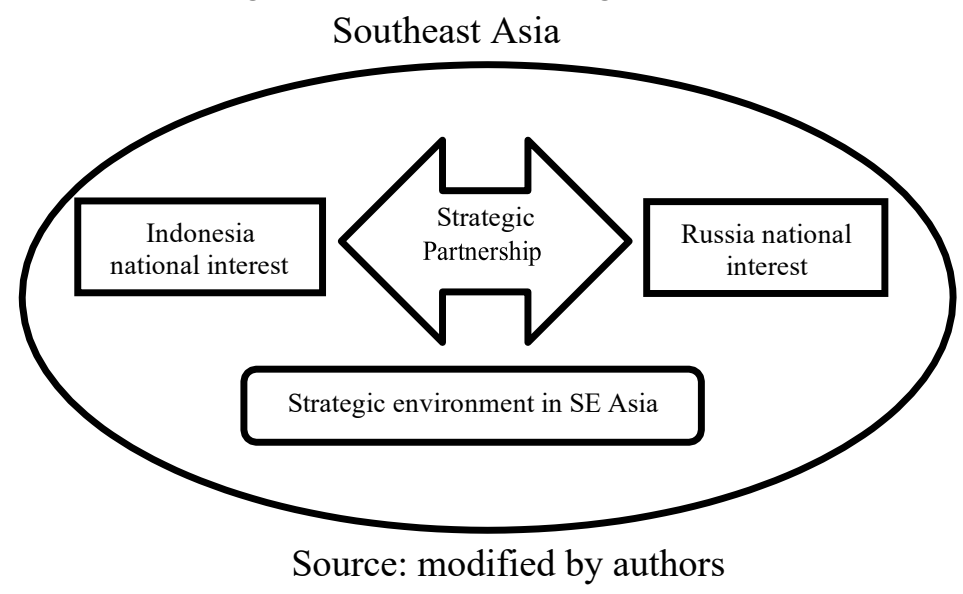

For Indonesia, the optimal role of the government in realizing the stability and security of a strategic environment is also an integral part of Indonesia's national interests, so that Indonesia has specific interest to monitor developments in situations that threaten world peace and regional stability in order to make concrete and constructive decisions. Henceforward, in responding to its strategic environment in Southeast Asia, thus, the development of this defense architecture is realized through the smart power defense strategy approach, which is a synergistic combination of the building of hard power and soft power based on strategic rational decisions. Indonesia needs to be supported by reliable, adequate and independent defense tools and infrastructure, where partnerships with other countries need to be forged continuously, especially with Russia. This is related to Jakarta's response to the rivalry between the US and China in the South China Sea, which is directly adjacent to the Southeast Asian region.

\footnotetext{
${ }^{4}$ Kementerian Pertahanan Republik Indonesia. (2018, February 5). Kebijakan Pertahanan Negara Tahun 2018. Wira Edisi Januari-Pebruari 2018 Volume 70 Nomor 54. Retrieved 5 January 2021. https://www.kemhan.go.id/wpcontent/uploads/2018/03/wirajanfeb18-websitekemhanOK.pdf.
} 
But, up to 2021, that a corresponding declaration on strategic partnership between Indonesia and Russia has not been signed yet ${ }^{5}$. Indonesia and Russia friendly relations in the defense security sectors have been established for a very long time ${ }^{6}$. Indonesia needs to partner strategically with Russia to improve the capability of an independent domestic defense industry. The strength of the defense industry owned by a country will later reflect how the country's economic strength itself is able to compete in the international market. Like several developed countries in the world today, such as the US, Russia, China, the UK, France and India, whose economies are developed due to the advanced defense industry supports.

Indonesia is an archipelago with about 17 thousand islands. As an open archipelago country that should have a maritime vision, all of Indonesia's defense potential must be able to be optimized, especially with the strengthening of the navy, especially for early prevention and deterrence in offshore areas that are unique to Indonesia as a maritime country. Among the considerations that are referred to are those related to the country's geostrategic factors internal and externally. Thus, the national defense system must pay attention to the characteristics of Indonesia as the largest archipelagic country in the world, inhabited by 270.2 million inhabitants ${ }^{7}$. Indonesia has an area of 7.7 million $\mathrm{km} 2$, including an exclusive economic zone with a coastline of about 80 thousand kilometers.

5 ТАСС. 2020. Шойгу: отношения РФ и Индонезии могут выйти на уровень стратегического партнерства. TASS 28 января 2020. Retrieved 30 January 2020. https://tass.ru/armiya-i-opk/7625561.

6 Посольство Республики Индонезия в Российской Федерации и Республике Беларусь. Министр обороны Прабово встретился с министром обороны России для обсуждения расширения сотрудничества, 30 января 2020 г. Дата обращения 5 октября 2020. https://kemlu.go.id/moscow/lc/news/4498.

${ }^{7}$ Badan Pusat Statistik Republik Indonesia. 2020. Sensus Penduduk 2020. Retrieved 3 February 2021. https://www.bps.go.id/sp2020/
Apart from strategic factors, Indonesia's defense strategy must also pay attention to other external factors, namely the dynamics that occur in the international environment, such as those related to the changing nature of war, the nature and form of military threats from foreign countries in a world driven by rapid developments in the field of digital information technology ${ }^{8}$. Modern war in the era of the current digital information revolution will not possibly be dominated by territorial warfare carried out with the concepts of guerrilla armed resistance, but rather a war that emphasizes the destruction of vital infrastructure and the center of gravitate.

Advances in information technology and weapons are supported by the use of artificial intelligence through the use of intercontinental ballistic missiles and drones. In fact, as it has blurred the territorial boundaries of the nationstate, the nature of war has become more rapid and effective. Meanwhile, indications of state sovereignty and security are likely to be increasingly prone to any preemptive attack and demand sustainable, dynamic and efficient development and management of economic and defense forces.

Russia's interests in the Southeast Asia are determined by a complex set of objective factors combined with subjective ones like the specific features of its self-perception and selfpositioning on the international stage ${ }^{9}$. These interests are fairly general in nature and boil down to containing challenges to national security and searching for opportunities for stable socio-economic development. Russia and Indonesia relations, including through the military cooperation, have all the prerequisites for reaching the strategic level. Russia views

\footnotetext{
${ }^{8}$ Arry Bainus. 2018. Mengatur Tentara. UNPAD Press, Bandung, Indonesia, p. 303

${ }^{9}$ Президент России. 2018. Саммит Россия - ACEAH. Кремль , 14 ноября 2018 года. Дата обращения 3 января 2021 http://www.kremlin.ru/events/president/news/59120.
} 
Indonesia as one of the most important partners in Asia-Pacific region, interaction with which is traditionally based on friendship and mutual trust which there are prerequisites for bringing bilateral ties to the level of strategic partnership ${ }^{10}$.

Jakarta did hard work to pursuit its national interest in further strengthening relations with Moscow. Indonesia and Russia agreed to remove trade barriers in order to achieve the target trade volume. This agreement was reached by the $4^{\text {th }}$ Indonesia - Russia Bilateral Consultation Forum, which took place virtually ${ }^{11}$. Cooperation between the two countries will be carried out through the development of a more action-oriented strategic partnership, strengthening economic diplomacy and refocusing cooperation priorities in the new normal era. To resolve trade barriers, both countries agreed on the need for a special discussion that also involved the stakeholders of the two countries (one-and-half track) in order to achieve the trade volume target of US\$ 5 billion. While, Russia's geostrategic interests reflected the idea of the country's return to the world stage as a great power ${ }^{12}$. Moscow showed that it is indispensable in the global fight against international terrorism, and this could contribute to improving relations with the West, which have been going through a rough time. Compared with Ukrainian issue of Crimea

\footnotetext{
10 ТАСС. 2020. Шойгу: отношения РФ и Индонезии могут выйти на уровень стратегического партнерства. TASS 28 января 2020 года. Дата обращения 30 января 2021 г . https://tass.ru/armiya-iopk/7625561.

${ }^{11}$ Kementerian Luar Negeri Republik Indonesia. 2021. Indonesia-Rusia Berkomitmen Tuntaskan Hambatan Perdagangan Kedua Negara, 3 January 2021. Direktorat Jenderal Amerika dan Eropa Kemenlu. Retrieved 4 January 2021.

https://kemlu.go.id/portal/id/read/2218/berita/indonesiarusia-berkomitmen-tuntaskan-hambatan-perdagangankedua-negara.

${ }^{12}$ Коммерсантъ. 2014. Запад должен пойти навстречу России. Журнал "Коммерсанть Власть" №11 от 24.03.2014, стр. 18. Дата обращения 10 декабря 2020 г. https://www.kommersant.ru/doc/2422597.
}

annexation by Russia in $2014^{13}$, where the development of the domestic situation and the policies of outside actors led to an inevitable clash between the Russian and Western approaches, the Southeast Asia did not look toxic and could even serve as a platform for coordinating efforts.

For more than five decades, Southeast Asian region is not a sphere of ideological and political battles or even given different approaches, and the US and other countries in the West did not view Russia's policies here as a radical challenge, since the preferences of local states seemed to have been long set and could not undergo any major adjustments. Most regimes seemed to be firmly pro-Western while Russia's military, political and economic capabilities can be identified as indicators of its political success. They were significantly below those of the US and its allies ${ }^{14}$. Russian leaders feel that the United States and its allies have ignored Russian interests and attempts at cooperation in the post-Cold War period ${ }^{15}$. Despite or indeed because of the advantages that NATO's overall superiority provides ${ }^{16}$, this superiority also has the potential to make certain types of Russian aggression morel likely ${ }^{17}$. When a state perceives the overall balance of power to be in another state's favor, particularly if that state is a potential adversary, this fuels security concerns ${ }^{18}$. In 2014, Putin argued that Russian global interests have been similarly ignored $^{19}$. The US, in his view, built a biased

\footnotetext{
13 The European Parliament. The EU and Russia: Locked into confrontation. 28 July 2020. Retrieved 3 January 2021. https://www.europarl.europa.eu/thinktank/en/document.htm 1?reference=EPRS BRI(2020)652030.

14 Bryan Frederick, Matthew Povlock, Stephen Watts, Miranda Priebe and Edward Geist, Assessing Russia Reactions to U.S. and NATO Posture Enhancements, 2017, Santa Monica, California: Rand Corporation, p. 29

${ }^{15}$ Ibid.

${ }^{16}$ Bryan Frederick et. all, Op.Cit., p.26

${ }^{17}$ Bryan Frederick et. all, Op.Cit., p.30

${ }^{18}$ John J. Mearsheimer, Conventional Deterrence, 1983, Ithaca, NY: Cornell University Press, p. 53

${ }^{19}$ Bryan Frederick et. all, Op.Cit., p.30
} 
international order and consistently violated international rules to promote its own interests at the expense of other states ${ }^{20}$.

Russia's regional interests included counteracting major challenges such transnational terrorism, well-known regime change policies, and steering a course for developing trade ties, attracting foreign investment, gaining access to the arms market and influencing oil prices. Russia's turn towards the Southeast Asia region, which was sealed by strengthening bilateral relations with Indonesia in March 2018, was apparently the result of ambition with the prior strategy on the global stage, rather than from a carefully considered choice. Russia's effective exclusion from the European security system has forced the country's leadership to treat with increasing concern the attempts of the US and its European partners to transform the end of the Cold War into their ideological, political and military victory. Considering Russia's intent to gain a more substantial presence on the global stage and have its role recognized by the international community, the Southeast Asia was the best fit for the purpose.

First, the fairly long and still unfinished search for a national identity prompted Russia towards its customary and historically global role. Yet this process was accompanied by sometimes objective, sometimes forced positioning between the West and the East. Although this tenet remained controversial from the civilizational point of view, its translation into political practice stressed the real need to develop relations with Asia and could, among other things, explain the activism in the Southeast Asia and the choice of regional partners. Second, significant experience of collaboration with regional forces was accumulated back in Soviet times.

Russia a challenged question with regards to Southeast Asia is at how Kremlin will

${ }^{20}$ Ibid. involve in relations within the region ${ }^{21}$. Russian current policy of practical, neutral position maintained progressively, but step by step more influential in the Southeast Asia's geopolitics landscape due to the activation of economic diplomacy. The best strategy is engage in a constructive dialogue sustainably with Southeast Asia's countries. In turn, it will boost Russia's strategic cooperation with multilateral institutions and broad range of collaborative goals.

The term regionalization is quite applicable to Russia's policies and signifies its turn towards relations with local powers, the manner of its application to the processes in Southeast Asia is still not entirely clarified. In international relations, regionalization usually refers to such phenomena as the revival or rise of regional powers and the shaping of regional integration alliances, including preferential groupings $^{22}$. Thus, the rise of Southeast Asian powers is still unquestionable. It has not happened against the background of integration trends, but rather has been provoked by the weakening of existing ties and organizations. What matters in this context is determining how conducive the processes in Southeast Asia are to achieving Russia's foreign political objectives and how effective the instruments Moscow has chosen are in this particular region, and mostly Indonesia.

On 28 June 2019, Russia government vows stronger ties with Indonesia and the Association of Southeast Asian Nations ${ }^{23}$. At

21 Tomasz Burdzik. 2019. Slowly but Surely: Russia's Foreign Policy in Southeast Asia, 11 September 2019. Retrieved 3 January 2020. https://russiancouncil.ru/en/analytics-andcomments/columns/asian-kaleidoscope/slowly-but-surelyrussia-s-foreign-policy-in-southeast-asia

${ }^{22}$ A. D. Voskresensky, E. V. Koldunova, E. A. Pronin. 2012. Regionalization in International Relations // International Relations Today. A. V. Torkunov, A. V. Malgin, eds. Moscow, Aspect Press, p. 107

${ }^{23}$ Novan Iman Santosa. 2019. Russia vows stronger ties with Indonesia, ASEAN. The Jakarta Post July 1, 2019. $\begin{array}{llll}\text { Retrieved } & \text { March } & 3020 .\end{array}$ 
international level, state relations grow dynamically in scrutinize cross-cutting, to be aware by policy-makers. The liberal democracy world develops along with new concepts, innovative school of thoughts, digitalized systems, and multi-level actors. Well, it depends on leaders' perspective. In international system, globalized world should be workable with economic diplomacy and focus on all diplomatic resources, policy implementation, and appropriate strategies in order to pursue foreign policy optimally.

\section{Indonesia Policies: Global Challenges}

During the global pandemic, Indonesian policy direction in 2021 is still considered to be in line with the various recent regional and global geopolitical challenges today. However, Indonesia diplomacy still needs to focus on the availability of available diplomatic resources so that these various policies can be optimally realized and able to solve any international problems.

Minister Retno Marsudi in her annual press statement stated 5 Indonesia diplomacy priorities $^{24}$ : 1) Building national health independence and resilience; 2) Supporting economic recovery and green development or sustainable development; 3) Strengthening the protection system for Indonesian citizens; 4) Continuing to contribute to advancing various regional and world issues; 5) Protecting state sovereignty and national territories ${ }^{25}$. The tourism, health and education sectors will be the main focus Indonesia and Russia as Jakarta appreciates the progress of bilateral relations in the economic sector, especially in relation to boosting Russian investment in Indonesia and plans to increase investment in the oil, plantation and high technology sectors. On the other hand,

https://www.thejakartapost.com/news/2019/07/01/russiavows-stronger-ties-with-indonesia-asean.html

${ }^{24}$ Kompas. 2021. Politik Luar Negeri RI Sesuai Tantangan,

7 January 2021.

${ }^{25}$ Ibid.
Russia will also support the acceleration of the formation of the FTA Indonesia - Eurasian Economic Union (EAEU) which has been in effect since $2019^{26}$.

Russia is one of Indonesia's largest trading partners and sources of investment, with an average trade balance in the last 5 years of US\$ 2.3 billion. In the midst of the COVID-19 pandemic, the 2020 trade balance was able to record a surplus on the Indonesian side of US\$ 16 million, with a total trade volume of US\$ 1.93 billion. On the other hand, the value of Russia's direct investment in 2020 was recorded at US\$ 4.6 million with 202 projects mostly in the chemical and pharmaceutical industry sectors ${ }^{27}$.

For Indonesia, 2020 is a very tough moment. However, the global pandemic has provided valuable lessons on the meaning and importance of strengthening sustainable global cooperation. Indonesia has a free and active foreign policy. Indonesia does not want to be only an object in international political competition involving the major world countries, Indonesia must be able to become a subject that has the right to determine its fate and future in the midst of the international system ${ }^{28}$. It is not easy to restart the national economy in the midst of a pandemic and fierce competition from major powerful state-actors, i.e.: China, the US, and the EU. Until now, the dispute between the US and China in the South China Sea has not yet

\footnotetext{
${ }^{26}$ Kementerian Luar Negeri Republik Indonesia. 2021. Indonesia-Rusia Berkomitmen Tuntaskan Hambatan Perdagangan Kedua Negara, 3 January 2021. Direktorat Jenderal Amerika dan Eropa Kemenlu. Retrieved 4 January 2021.

https://kemlu.go.id/portal/id/read/2218/berita/indonesiarusia-berkomitmen-tuntaskan-hambatan-perdagangankedua-negara.

${ }^{27}$ Kementerian Luar Negeri Republik Indonesia. 2021. Indonesia-Rusia Berkomitmen Tuntaskan Hambatan Perdagangan Kedua Negara, 3 January 2021. Direktorat Jenderal Amerika dan Eropa Kemenlu. Retrieved 4 January 2021.

https://kemlu.go.id/portal/id/read/2218/berita/indonesiarusia-berkomitmen-tuntaskan-hambatan-perdagangankedua-negara

${ }^{28}$ Kompas. 2021. Politik Luar Negeri RI Sesuai Tantangan, 7 January 2021.
} 
subsided. Still, Indonesia needs to continuously anticipate and respond to any impacts of conflicting competition that arise.

For Jakarta, the availability of vaccines from a number of vaccine manufacturers has generated new optimism. However, equality of access to vaccine availability remains a challenge, especially in the first and second quarters of 2021. The availability of the COVID19 vaccine raises new hope as the progress of economic activity at a global, regional and national level is tapped. The IMF predicts that global economy is 5.2 percent; even Asian region can reach 6.9 percent $^{29}$.

To support economic recovery and green or sustainable development, the Indonesian government is encouraging the implementation of an agreement on travel corridor arrangements in ASEAN, known as ASEAN TCA, the use of the APEC Travel Card, and various other TCA agreements. In addition, Jakarta is also ready to encourage the expansion of foreign investment into Indonesia, expansion of world market access, and regional integration through the ratification and implementation of a number of economic partnerships. A number of Indonesian economic partnerships, including: Indonesia and Australia and Indonesia with South Korea.

Indonesia also plans a target of finalizing its economic partnership with the European Union and Turkey, as well as starting trade negotiations with Serbia, the EAEU, and the creation of a limited trade agreement with the US. Obviously, Indonesian diplomacy stands tall, has dignity, fights for national interests and contributes to world peace and stability. Indonesia has always been consistent, making the implementation of foreign policy part of solving world problems.

Previously, Foreign Minister Retno Marsudi conveyed the priorities of foreign policy for 2020 and the direction of the next 5 years. Indonesian diplomacy will be carried out based

${ }^{29}$ Ibid. on $4+1$ priorities, namely ${ }^{30}:$ 1) Strengthening economic diplomacy ${ }^{31}$; 2) Protection diplomacy $^{32}$; 3) Sovereignty and national diplomacy $^{33}$; 4) Indonesia's role in the region and globally ${ }^{34}$. Meanwhile, the one plus is the strengthening of the diplomatic infrastructure ${ }^{35}$. Thereafter, in the next 5 years, from 2020 to 2025, economic diplomacy will be truly strengthened and become the cornerstone of Indonesia's diplomacy abroad. The Deputy Minister of Foreign Affairs has also received a special assignment from Indonesian President to strengthen diplomacy of economy. These concrete assignments will be given to the Heads of Representatives in strengthening sustainable economic diplomacy and providing benefits to the national economy.

Meanwhile, from 2018 to early 2021, Beijing and Washington D.C's rivalries has shown the expansion of the issue to various sectors, where it is not yet known how to proceed and how to resolve $\mathrm{it}^{36}$. The competition between the US and China in the South China Sea has a significant impact on global multilateralism. Countries like Indonesia have been relying on multilateralism to pursue their national interests in international relations. The multilateralism approach allows middle power countries like Indonesia to face big powers. On the other hand, the US and China tend to encourage and take advantage of bilateral approaches in the international system. During the administration of President Donald Trump

\footnotetext{
${ }^{30}$ Indonesia Ministry of Foreign Affairs. 2020. Pernyataan Pers Tahunan Menteri Luar Negeri RI 2020: Prioritas Diplomasi 4+1 \#Diplomacy4PeaceandProsperity. 8 January 2020. Retrieved 10 January 2020. https://kemlu.go.id/ankara/id/news/4152/pernyataan-perstahunan-menteri-luar-negeri-ri-2020-prioritas-diplomasi41-diplomacy4peaceandprosperity.

${ }^{31}$ Ibid.

${ }^{32}$ Ibid.

${ }^{33}$ Ibid.

${ }^{34}$ Ibid.

${ }^{35}$ Ibid.

${ }^{36}$ Kompas. 2020. Persaingan AS-China: Asia Tenggara Paling Terdampak, 24 July 2020.
} 
(2016-2020), the US increasingly showed a tendency to move away from multilateralism by leaving a number of international organizations.

The US and China are important economic partners for the region. Beijing and Washington D.C are among the main export destinations and investment origins for Southeast Asia. The Southeast Asian production chain also relies heavily on permits for various US patents and raw materials or intermediate products exported from China. The US and the EU admit China's dominance in international politics, as the main source of various raw materials and intermediate products in the various production processes of their manufacturing industries. Countries in the Southeast Asian region will play it safe and comfortable position.

The US-China feud will not lead to an open arms conflict. Washington, D.C and China are still showing signs of avoiding open military conflict in the South China Sea, even though they both continue to mutually deploy their war assets. Beijing continues to try to hold back and not be provoked by the US. Beijing understands that the deployment of the military power of the US and its allies is only symbolic. China is aware that the current tensions with the US are only situational and temporary. Most likely, during the leadership of US President Joe Biden (2020-2024), the conflict of these global major powers will still take place in other forms, such as economic sanctions.

This major powers rivalry has made the Southeast Asia region affected. Regional economic development and growth can be disrupted in connection with the achievement of regional economic stability and security.

The development of Russian-Indonesian relations in 2014 deserves the most positive assessment. Both countries are able to significantly expand our political dialogue and give it greater confidence, offered to discuss large promising projects of economic cooperation. Most importantly, both major powers managed to establish really strong and broad contacts with the administration of the new President of Indonesia, Joko Widodo, who took office in October 20, $2014^{37}$.

The great importance of the first meeting between Russian President Vladimir Putin and Indonesian President Joko Widodo crystalized at APEC summit in China capital city in November 2014. It happened in a very constructive atmosphere and made it possible to establish contact between two leaders. Mutual understanding and a clear agreement were reached on the intensification of strategic bilateral relations and their broad development in all areas, including trade and economic cooperation, interaction in international affairs, scientific and technical cooperation in the spirit of mutual partnership and mutual benefit.

During Russia and ASEAN Summit Leaders in November 2018 in Singapore, President Putin also met with President Jokowi. The agenda of the meeting with the leadership of these countries in Singapore includes topical issues of the development of the Russia-ASEAN dialogue, issues of trade and economic cooperation, promotion of ASEAN contacts with the Eurasian Economic Union (EAEU) and the Shanghai Cooperation Organization $(\mathrm{SCO})^{38}$, including in the context of the prospects for the Greater Eurasian Partnership formation ${ }^{39}$. It put collaborative efforts in countering modern challenges and threats, first of all, terrorism and transnational crime, including foreign terrorist fighters. All leaders also focus on the most pressing international topics, including the

\footnotetext{
37 Посольство Российской Федерации в Республике Индонезия. 2015. Интервью Посла России в Индонезии М.Ю.Галузина информагентству «Россия сегодня». 10 февраля 2015 г. https://indonesia.mid.ru/posol-rossii-vindonezii-o-dvustoronnem-sotrudnicestve//asset publisher/VQ4x2Q4Lat4O/content/interv-u-poslarossii-v-indonezii-m-u-galuzina-informagentstvu-rossiasegodna-?

${ }_{38}$ Tass.ru. 2018. Путин выступит на саммите РоссияАСЕАН, встретится с лидерами Японии и Южной Кореи. 14 ноября 2018 г. https://tass.ru/politika/5789487 ${ }^{39}$ Ibid.
} 
nuclear issue of the Korean Peninsula and Syrian conflict.

\section{Russia-ASEAN Relations}

ASEAN and Russia began in 1991 and were accepted as ASEAN Full Partner in 1996, ${ }^{40}$ previous such summit was held in Sochi in $2016^{41}$. The political and security cooperation relations between ASEAN and Russia maintain sustainably. ASEAN-Russia entered 25 years of partnership in 2021. So far, Russia has often been an important partner in maintaining stability and security in the region.

During 2018 to 2021, various achievements that have taken place in enhancing ASEAN and Russia relations include increasing Russia's partnership to become an ASEAN strategic partner in $2018^{42}$, providing training for research in the field of science, information technology cooperation, encourage formation a partnership fund that can assist in the development of cooperative projects.

At the $17^{\text {th }}$ annual meeting of ASEANRussia Senior Officials' Meeting/ARSOM which was held on January 26, 2021 via video conference, ASEAN and Russia agreed to increase cooperation in responding to challenges in the region due to the pandemic, maintaining stability and security and strengthen economic

\footnotetext{
${ }^{40}$ Indonesia Ministry of Foreign Affairs. 2021. ASEANRussia Senior Officials Meeting (ARSOM) Ke-17: Implementasi ASEAN-Outlook on the Indo-Pacific adalah kunci untuk pemulihan pandemi. 27 January 2021. https://kemlu.go.id/portal/id/read/2104/view/asean-russiasenior-officials-meeting-arsom-ke-17-implementasi-aseanoutlook-on-the-indo-pacific-adalah-kunci-untuk-pemulihanpandemi

${ }^{41}$ Tass.ru. 2018. Путин выступит на саммите РоссияАСЕАН, встретится с лидерами Японии и Южной Кореи. 14 ноября 2018 г. https://tass.ru/politika/5789487

${ }^{42}$ Indonesia Ministry of Foreign Affairs. 2021. ASEANRussia Senior Officials Meeting (ARSOM) Ke-17: Kementerian Luar Negeri Republik Indonesia. 2021. Implementasi ASEAN-Outlook on the Indo-Pacific adalah kunci untuk pemulihan pandemi. 27 January 2021. https://kemlu.go.id/portal/id/read/2104/view/asean-russiasenior-officials-meeting-arsom-ke-17-implementasi-aseanoutlook-on-the-indo-pacific-adalah-kunci-untuk-pemulihanpandemi
}

recovery efforts ${ }^{43}$. Entering 25 years of ASEANRussia partnership, Indonesia believes that ASEAN and Russia can play a more strategic role to maintain regional stability with ASEAN community welfare contribution targets.

Further, the AOIP constructed as holistic and impartial concept. It emphasizes the importance of cultural dialogue to solving various problems in the Indo-Pacific, including collaborative efforts to recover the postpandemic economy, in addition to the importance of prioritizing the importance of ASEAN Centrality in facing current global challenges and encouraging Russia to collaborate with ASEAN under the AOIP.

Russia and ASEAN partnership efforts to dealing with turmoil in the region, including handling the threat of terrorism and trans-border crime which is considered to continue to be a threat, amid the increasing use of the internet during the pandemic. Russia is proposing capacity building cooperation for ASEAN officials to deal with cyber threats.

In the economic sector, ASEAN and Russia agreed to encourage joint efforts to restore the economy in the region and to further enhance trade contacts between ASEAN and Eurasia Economic countries-members and Shanghai Cooperation Organization, experts exchange to advance regional digital economy, and cooperation to encourage smart cities development.

In the socio-cultural field, Russia also supports strengthening the capacity of public health and emergency response to pandemics within various ASEAN frameworks. Russia is also offering the Sputnik $V$ vaccine to meet

\footnotetext{
${ }^{43}$ Indonesia Ministry of Foreign Affairs. 2021. ASEANRussia Senior Officials Meeting (ARSOM) Ke-17: Implementasi ASEAN-Outlook on the Indo-Pacific Adalah Kunci untuk Pemulihan Pandemi. 27 January 2021. Retrieved $30 \quad$ January 2021. https://kemlu.go.id/portal/id/read/2104/view/asean-russiasenior-officials-meeting-arsom-ke-17-implementasi-aseanoutlook-on-the-indo-pacific-adalah-kunci-untuk-pemulihanpandemi
} 
vaccine needs in the region. In addition, a Memorandum of Understanding for Disaster Management was agreed between ASEAN and Russia to help increase cooperation in the field of ASEAN disaster management with Russia.

For last six years, Russia's cooperation with 10 countries in Southeast Asia that are members of ASEAN, has opened up opportunities for closer cooperation with Indonesia in order to open export markets to various countries in the Central Asian region. It is certain that after two decades, the Kremlin is now getting closer to establishing and strengthening solid cooperation with ASEAN countries, including Indonesia, along with multilateral cooperation framework with ASEAN.

Indonesia views Russia at this time as quite important as a strategic trading partner in the Central Asia region. Thus, Indonesia needs to develop trade with the countries of central Asia, the former Soviet Union.

Currently, Indonesia is getting more benefits from Russia from trade than Russia for Indonesia, because Russian products in Indonesia, such as automotive and machinery, have a cheaper substitution than Russia.

Meanwhile for Indonesia, it is difficult to find substitutes for consumer products such as crude palm oil and other consumer goods in Russia. Moreover, currently Indonesian crude palm oil is facing obstacles to access to the European Union market, so Indonesia needs to get a new market for Indonesian CPO production. In addition, the Central Asian market has more potential than Africa, and it is only natural for the Indonesian government to open closer diplomatic relations with Russia. So far, the momentum of trade volume between Indonesia and Russia is more favorable for Indonesia, where Indonesia enjoys a trade transaction surplus. It is expected that the current close cooperation with Russia will further enlarge the surplus going forward.
Indonesia has increased to export palm oil to Russia by 1 million tons in $2019^{44}$. Most Russians use palm oil for industrial needs instead for daily consumption. Russia has promised to maintain the level of imports of CPO and will not be reduced even though the commodity is facing restrictions in EU countries.

Thereafter, from 14 to 17 December 2020 , in order to develop military cooperation between both countries, as well as within the framework of the celebration of the $70^{\text {th }}$ anniversary of bilateral relations, a detachment of ships of the Russian Pacific Fleet, including the guardian Varyag Cruiser ship and antisubmarine Panteleev Admiral anti-submarine vessel has arrived in the world largest archipelagic state ${ }^{45}$. On the Russian side, the ships were met by the Russian Ambassador to Indonesia Lyudmila Vorobyova and the Military, Naval and Air Force Attaché at Russian Embassy, $1^{\text {st }}$ Rank Captain Sergei Zhevnovaty, from Indonesia side represented by Ministry of Defense, servicemen of the naval base in Surabaya.

\footnotetext{
44 The Indonesia Oil Palm Plantations Fund Management Agency. 2019. Palm Oil Products Attract Russians at Festival Indonesia, 4 August 2019. Retrieved 5 January 2021. http://www.bpdp.or.id/en/palm-oil-products-attractrussians-at-festival-indonesia

45 Посольство Российской Федерации в Республике Индонезия. 2020. ПРЕСС-РЕЛИЗ: $О$ ЗАХОДЕ КОРАБЛЕЙ ТИХООКЕАНСКОГО ФЛОТА ВМФ РОССИИ, 18 декабря 2020 г. Retrieved 6 January 2021. https://indonesia.mid.ru/arhiv-novostej-2020//asset publisher/O1EcZeZJvpd5/content/o-zahodekorablej-tihookeanskogo-flota-vmf-rossii?
} 


\section{Indonesia-Russia Relations: Southeast \& Central Asia}

ASEAN has been growing into a serious actor on the energy map of the Asia Pacific ${ }^{46}$. Having to a large extent an underdeveloped energy sector, Southeast Asian nations seek to position themselves as large and responsible resource consumers as well as a top spot for foreign investment. It presents new opportunities for Russia in terms of diversifying energy exports and promoting Russian technologies and equipment in Asia. In addition, active participation in multilateral cooperation in the Asia Pacific offers Russia a chance to be regarded here not only as a resource-rich energy provider but an influential and reputable policy maker.

Russian integrated energy company headquartered in Moscow, known as Rosneft Oil Company is aiming to expand its list of strategic partners in Asia via Indonesia ${ }^{47}$. Rosneft is aiming to expand its list of strategic partners in Asia via Indonesia ${ }^{48}$. In 2015, when the two countries celebrated sixty five years of diplomatic ties (1950-2015), Russia's President Vladimir Putin touched on his country's readiness to boosting up cooperation, as part of an effort to guarantee stability and security in the Asia-Pacific region. It followed at a bilateral meeting with Putin in May 2016 in Sochi. President Joko Widodo expressed Indonesia's strategic interest with Moscow, particularly at expanding closer cooperation in trade, politics and culture.

\footnotetext{
$46 \quad$ Oleg Kopylov. 2012. ЭНЕРГЕТИЧЕСКОЕ СОТРУДНИЧЕСТВО $B$ ИНТЕГРАЦИОННОМ КОНТЕКСТЕ ЮВА И АТР: НОВЫЕ ВОЗМОЖНОСТИ

ДЛЯ РОССИИ. Retrieved on 5 January 2021. https://indonesia.mid.ru/-/energeticeskoe-sotrudnicestvo-vintegracionnom-kontekste-uva-i-atr-oleg-kopylov-?

${ }^{47}$ Olga Mordyushenko and Dmitry Kozlov. 2016. Rosneft focuses on development in Indonesia. Kommersant. 5 May 2016. Retrieved 30 June 2020. https://www.rbth.com/economics/business/2016/05/05/rosn eft-focus-on-development-in-indonesia 590239 on 10 September 2019

${ }^{48}$ Ibid.
}

Russia recognized that Indonesia continues to play a more prominent role with its Global Maritime Fulcrum in Souheast Asia and the broader Asia-Pacific region, its deepening ties and intensive engagement with Russia may prove to be noteworthy in the bilateral, regional and global context. During Cold War period, Russia experienced monumental relations with Vietnam from 1968 to 1975.

President Joko Widodo, thus, focuses on the inter-linkage of foreign policy, diplomacy economy, and maritime diplomacy continuously, i.e.: sovereignty, defense, protection of Indonesia citizen abroad, and strengthening bilateral economy relations.

In the momentum of major powers competition, Indonesia as Southeast Asia regional leader should involve actively to determine its bargaining power as pluralist democratic state to overcome regional and global problems. While in international politics, Indonesia influence cannot be ignored and should be considered by other major powers in overcoming world economic unfairness; poverty reduction; human trafficking, food and energy security; environmental degradation; illegal logging, and natural disaster. At national level, Indonesia Parliament also support the implementation of active and free foreign policy in challenging global competition, democracy, and free trade regime ${ }^{49}$.

President Putin did one-day visit to Jakarta on 6 September $2007^{50}$. Indonesia needs to maximize and empower its efforts, resources competitiveness, strategic location and geopolitics in directing how to challenge Global

\footnotetext{
${ }^{49}$ Noor Fardiansah. 2009. DPR Dukung Penuh Kebijakan Politik Bebas Aktif, 13 February 2019. http://www.mediaindonesia.com.

${ }^{50}$ Ingo Waldelt. 2007. Between Economic and Security Interests: Russia's Return to the Indonesian Archipelago, 3 November 2007. Retrieved 30 June 2020. https://www.watchindonesia.org/17629/russias-return-tothe-indonesian-archipelago?lang=en
} 
Maritime Fulcrum in world politics ${ }^{51}$. The implication of state willingness to be a regional actor and even international actor is the realization of state outward looking military capability development. It is a readiness of state military capability to counter and enclose external threat beyond its broader territory and sovereignty. Manurung stated that Russia supports Indonesia as the global maritime fulcrum $^{52}$, with a background of world maritime powers. The two countries have the potential to establish easier cooperation in the maritime sector. In 2014, the Kremlin highly appreciates President Joko Widodo's insightful idea to restore and strengthen Indonesia's position as a maritime country respected by world major powers $^{53}$.

In 2018, Russia has been going through quite challenging times ${ }^{54}$. Economic slowdown, a collapse in oil prices and Western sanctions has deprived Moscow of cheap money and technologies. All of these have pushed the Kremlin's strategists to concentrate on import substitution policy, the reorganization of import supply chains, decreasing dependency on oil exports and pushing for the country's pivot towards Asia.

Central Asia is a region that has international significance. Azerbaijan is estimated to have oil reserves of up to 7 billion

\footnotetext{
${ }^{51}$ Hendra Manurung. 2018. Menuju Poros Maritim Dunia: Masa Depan Indonesia. http://www.researchgate.net/publication/323369195_MEN UJU_POROS_MARITIM_DUNIA_MASA_DEPAN_IND ONESIA. DOI: $10.13140 / \bar{R} G \cdot 2.2 .3 \overline{5} 254.60489$, accessed on 15 February 2019.

52 Hendra Manurung. 2018. Indonesia Menuju Poros Maritim Dunia. Prosiding Seminar Nasional Pakar 2018 Buku II. Retrieved 18 December 2020. https://www.trijurnal.lemlit.trisakti.ac.id/index.php/pakar/ar ticle/view/2714

${ }^{53}$ Ranny Virginia Utami. 2014. Rusia Dukung Indonesia jadi Poros Maritim, 8 November 2014. Retrieved 30 December 2020 https://www.cnnindonesia.com/internasional/20141108105 016-134-10391/rusia-dukung-indonesia-jadi-poros-maritim ${ }^{54}$ The National Interest 2018. A Russian Pivot to Asia? 1 November 2018. Retrieved 30 December 2020. https://nationalinterest.org/feature/russian-pivot-asia-34892
}

barrels which is the $20^{\text {th }}$ largest in the world and 1.1 trillion cubic meters of natural gas reserves which is the $27^{\text {th }}$ largest in the world. Kazakhstan has oil reserves reaching 30 billion barrels which is the $12^{\text {th }}$ largest in the world and coal reserves reaching 33.6 billion tons which is the $8^{\text {th }}$ largest in the world. Turkmenistan is estimated to have natural gas reserves reaching 17.5 trillion cubic meters which is the $4^{\text {th }}$ largest in the world ${ }^{55}$. In terms of uranium reserves, Kazakhstan ${ }^{56}$ and Uzbekistan $^{57}$ each have 679,300 tons and 91,300 tons of uranium which are the $2^{\text {nd }}$ and $13^{\text {th }}$ largest in the world.

Apart from energy, Central Asia also has an economic potential utilized. With a population of around 77.3 million and Total GDP reached US\$ 353.7 million $^{58}$, Central Asia is a non-traditional market which is quite interesting to explore by Jakarta. The average economic growth of countries in the region also shows a positive trend, namely 6.5 percent in the period 2010-2015.

Meanwhile, for Indonesia, Central Asia is a region consisting of six states from the former Soviet Union, namely Azerbaijan, Kazakhstan, Kyrgyzstan, Tajikistan, Turkmenistan and Uzbekistan, which is an area that has abundant reserves of energy and mineral wealth. This area has a number of reserves of oil, natural gas, coal and uranium and has economic potential that can be exploited. This makes Central Asia a non-traditional market which is

\footnotetext{
${ }^{55}$ British Petroleum. 2016. BP Statistical Review of World Energy, June 2016. Retrieved 10 June 2020. http://oilproduction.net/files/especial-BP/bp-statisticalreview-of-world-energy-2016-full-report.pdf

${ }^{56}$ World Nuclear Association. 2021. Uranium and Nuclear Power in Kazakhstan, January 2021. Retrieved 11 June 2020. https://www.world-nuclear.org/informationlibrary/country-profiles/countries-g-n/kazakhstan.aspx

${ }^{57}$ World Nuclear Association. 2020. Uranium in Uzbekistan, February 2020. Retrieved 12 June 2020. https://www.world-nuclear.org/information-library/countryprofiles/countries-t-z/uzbekistan.aspx

${ }^{58}$ International Monetary Fund. 2016. World Economy

Outlook 2016. Retrieved 13 June 2020. https://www.imf.org/en/Publications/WEO/Issues/2016/12/ 31/Subdued-Demand-Symptoms-and-Remedies
} 
quite interesting, coupled with the average economic growth of countries in the region which shows a quite positive trend, namely 6.5 percent in 2010 to 2015.

There are two main sectors that become the destination for Indonesian foreign investment in the Central Asia region, both of which are closely related to natural resources, namely related sectors natural resources (oil and gas extraction, geological exploration) and the supporting service sector (mining, oil and gas processing, and energy transportation). In addition, the country is also actively developing infrastructure, so that this sector is a potential that the Indonesian government also needs to utilize optimally.

Thus, realizing that it is land-locked and seeing all the potential and its trade cooperation framework, Central Asia seeks to build an adequate connectivity network and is currently being developed. Among the Central Asian connectivity networks is the Trans-Asian Railway Network which will connect Vladivostok in Russia to Malaysia, the Great Asian Highway, as well as the existence of 20 (twenty) international airports in six Central Asian countries that are connected to major world cities.

Hence, seeing the enormous economic potential in Central Asia as well with a fairly advanced infrastructure development, this area is predicted to become a future economic area, reviving its past glory as a silk road. By looking at the development and economic potential in Central Asia, Indonesia is deemed necessary to be more active in exploiting the potential Central Asian countries as a potential market.

Russia did full support on Indonesia economics interests to access EAEU markets. Indonesia is intensively working together with EAEU on free trade agreement. Members of union comprise of Armenia, Belarus,
Kazakhstan, Kyrgyzstan and Russia ${ }^{59}$. Thus, Indonesia has special interest in boosting economic cooperation with Central Asia and must not be left behind with other countries in exploring and exploiting the economic benefits. Indonesia has economic interests, among others generating the export value of Indonesian products, attracting foreign investment from Central Asia as well as encouraging Indonesian investment in Central Asia, attracting more incoming foreign tourists from Central Asia, and encouraging more professional Indonesian workers to be sent to Central Asia.

It needs a mature, effective and measured strategy to carry out economic diplomacy to Central Asia, so that, Indonesia can participate optimize Central Asia regional potential. Indonesia must not be left behind in the competition to maximize the economic potential of Central Asia.

\section{Indonesia and Russia Economic Cooperation}

In the 1950s and early 1960s, the former Soviet Union shared close relations with Indonesia, during which former President Sukarno and Soviet leader Nikita Khurshchev visited each other's capital city. Relations between the USSR and Indonesia remained intact even under President Suharto's anticommunist regime, compared to the suspension of diplomatic relations between Indonesia and China from 1967 to 1990. At the 1980 Summer Olympics in Moscow, Indonesia was one of more than 60 countries boycotted the games in protest of the 1979 Soviet invasion to Afghanistan.

Post-Cold War in 1990s, Russian foreign policy since the collapse of the Soviet Union develops simultaneously on international

\footnotetext{
${ }^{59}$ Hendra Manurung. 2018. Indonesia and Russia Relations in Response with Changing Strategic Environment. Politica, Volume 9, Number 1, May 2018. Retrieved on 10 January 2020.

https://sdip.dpr.go.id/search/detail/category/Jurnal\%20Politi ca/id/535
} 
political agendas against the background of major new global and regional international trends, and the policy of other major world powers $^{60}$. Over the past two decades, economic cooperation between Russia and Southeast Asia has lagged behind political cooperation. ${ }^{61}$

In the first decade of the $21^{\text {st }}$ century, rapid acceleration of global processes emerge, and growing new trends in global development require new approaches to key aspects of the rapidly changing situation in the world and a new vision of priorities in Kremlin's policy, taking into account Russia's increased responsibility for setting the international agenda and shaping the system of international relations. Thus, the strategic partnership between the development strategies of Russia and China in bilateral, regional, and global relations lays the foundation of improvement cooperation between a number of countries, regions, and organizations ${ }^{62}$.

The red bear bombers visit to Indonesia marked the first such deployment since Cold War times, when Soviet maritime patrol planes flew over the Pacific from a base in Vietnam ${ }^{63}$. Since 2012, Indonesian economy with Russian Federation for last five years shows significant dynamic fluctuation. Based on Ministry of Trade Republic of Indonesia in 2017, Indonesia and Russia recorded a 19.7 percent increase in bilateral trade to US $\$ 2.5$ billion, with around 40

\footnotetext{
${ }^{60}$ Globalaffairs.ru. 2016. Global Challenges and Russia's Foreign Policy, 20 November 2016. Retrieved 3 January 2020. https://eng.globalaffairs.ru/articles/global-challengesand-russias-foreign-policy/

${ }^{61}$ Hendra Manurung. 2018. Indonesia and Russia Relations in Response with Changing Strategic Environment. Politica, Volume 9, Number 1, May 2018. Retrieved on 10 January 2020.

https://sdip.dpr.go.id/search/detail/category/Jurnal\%20Politi $\mathrm{ca} / \mathrm{id} / 535$

62 Hendra Manurung. 2019. Russia-China Strategic Partnership in the Indo-Pacific Region: Synergizing Greater Eurasia with Belt and Road Initiative, 2016-2018. Journal Asia Pacific Studies, Volume 3 Number 1/JanuaryJune 2019, pp. 25-42. DOI. http://dx.doi.org/10.33541/japs.v3i1.954

${ }^{63}$ Ibid.
}

percent of Indonesian exports to Russia comprising of palm oil products (Ministry of Trade, 2018).

\section{Indonesia-Russia trade (2013 - 2018, in thousands US\$)}

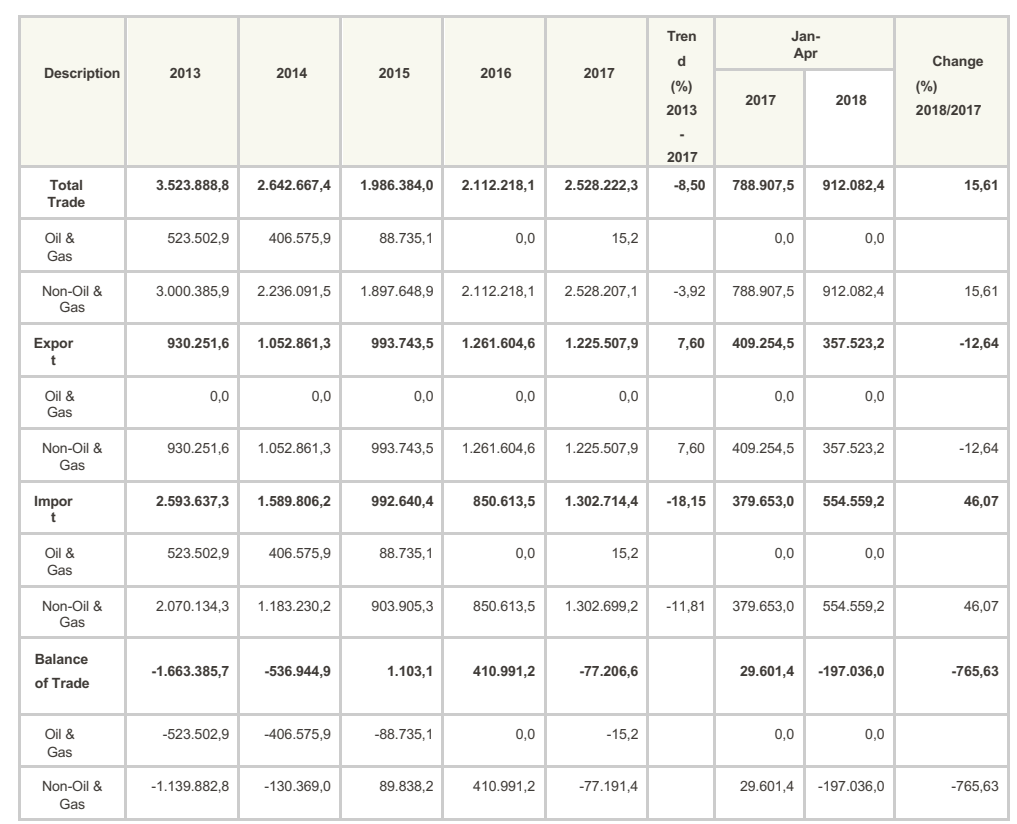

Source: BPS \& Indonesia Ministry of Trade (2018)

Indonesia seeks to tap into the Russian market, which has a total population of over 144 million people. With the support of Russia, Indonesia is also working with EAEU countries, such Russia, Armenia, Belarus, Kazakhstan, and Kyrgyzstan. In Jakarta, on February 14, 2019, Indonesia pioneered the beginning of trade talks and economic cooperation with five Eurasian countries who are members of the Eurasian Economic Union ${ }^{64}$. There is more than 110,000 Russian tourists visited Indonesia in 2017, a 27 percent increase from 2016. Russia also provided 161 scholarships for Indonesian students in 2017, an increase from 100 scholarships in 2016. The Russian Embassy in Jakarta is currently working to further increase the number of

${ }^{64}$ Hendra Manurung. 2020. Indonesia - EAEU relations: developing trade and economic cooperation, 14 September 2020. Retrieved 5 January 2021. https://miwiinstitut.de/archives/572 
scholarships it sponsors from Sabang to Merauke. In October 2020, Indonesia and Russia at the $4^{\text {th }}$ meeting of the Indonesian-Russian Working Group on Trade, Investment and Industry also discussed various obstacles, opportunities and breakthroughs to reduce barriers to export and import trade; exploring cooperation in developing strategic industries and handling COVID-19, including cooperation on vaccines; and encouraging increased participation of the business and private sectors in investment projects between the two countries ${ }^{65}$.

In March 2018, Indonesia unexpectedly found itself in the crossfire of a U.S-Russia diplomatic spat due to its decision to purchase 11 Russian Su-35 jet fighters ${ }^{66}$. The deal has stirred up discussions of what Russia's strategic interest in Indonesia is and how it fits into Indonesia national defense. Although the deal is not huge in scale but the cost is reported to be US\$1.14 billion $^{67}$, offset by barter mostly in palm oil and coffee.

Indonesia needs to optimize and take advantage of important trade economic relations with Russia, in which, the Kremlin has committed to further increase the volume of trade and expand investment with Indonesia. However, suppose through new strategic partnership signing agreement in the coming years will bind trustworthy friendship, strengthen mutual trust and synchronized collaborative synergy for both countries which need to form working groups across different sectors of closer cooperation to garner the benefit potential at hand.

${ }^{65}$ Warta Ekonomi. 2020. Indonesia-Rusia Tingkatkan Kerja Sama Perdagangan \& Investasi, 19 October 2020.

Wartaekonomi.co.id. Retrieved 5 January 2021. https://www.wartaekonomi.co.id/read309843/indonesiarusia-tingkatkan-kerja-sama-perdagangan-investasi

${ }_{66}$ Defenseworld.net. 2018. US Pressured Indonesia To Abandon Su-35 Fighter Jet Contract With Russia, 12 March 2018. Retrieved 5 January 2021. https://www.defenseworld.net/news/22128\#.W0Z22NIzbIX

${ }^{67}$ Ibid.

\section{Conclusion}

Indonesia with some Southeast Asian countries has welcomed Russia strategic position at playing greater security role, particularly in responding to the US and China rivalries in Asia Pacific.

For Indonesia, terrorism, nuclear proliferations, and regional instability currently top the list of international dangers facing and should be anticipated sooner or later. Until recently, open conflict with other international major powers still posed largest threats by Jakarta policy-makers with the South China Sea regional security tension involve China and the US rivalries nearby Indonesian backyard in North Natuna Sea region. At present, potential regional conflict closed to Indonesia Exclusive Economic Zone (EEZ) probably might happen.

During COVID-19 pandemic, growing China ambitious influence through its Belt and Road initiative may eventually challenge the US global powers. However, it needs regional concerns to strengthening bilateral cooperation vis a vis economic competition.

Regarding Indonesia's global position in the world geopolitical sphere of influences, Indonesia should be able reformulate strategic decision in international politics, increase bilateral and multilateral cooperation, in addition to advancing Indonesia's real presence with its various national agendas and embracing countries in the region to realize world peace and stability.

Currently, the challenge of Indonesia's positioning role is not only on the global stage, but also how it works at the Southeast Asian regional level, particularly with regard to Indonesia's ability to translate global norms into regional norms that become collective agreements. Domestic conditions also need to be a concern by Indonesian policy makers in order 
to decide what will be the best for the whole nations.

\section{Bibliography}

\section{Books}

Amitav, Acharya. 2012. The Making of Southeast Asia: International Relations of $A$ Region. Singapore: Institute of Southeast Asian Studies (ISEAS).

Bainus, Arry. 2018. Mengatur Tentara. UNPAD Press, Bandung, Indonesia,

Buzan, Barry et al. 2003. Regions and Powers the Structure of International Security. U.K: Cambridge University Press.

Buzan, Barry, Wæver, Ole and Wilde, Jaap. 1998. Security: A New Framework for Analysis. Boulder, CO: Lynne Rienner Publishers.

Carbaugh, R. 2010. International Economics. Ohio, USA: South Western.

Frederick, Bryan, Matthew Povlock, Watts, Stephen, Priebe, Miranda, and Geist, Edward. 2017. Assessing Russia Reactions to U.S. and NATO Posture Enhancements. Santa Monica, California: Rand Corporation

Mearsheimer, J, John. 1983. Conventional Deterrence. Ithaca, NY: Cornell University Press.

Voskresensky, A.D, Koldunova, E.V, Pronin, E.A. 2012. Regionalization in International Relations // International Relations Today. A. V. Torkunov, A. V. Malgin, eds. Moscow, Aspect Press.

\section{Government Documents}

ASEAN Chairman's Statement. 2017. The $30^{\text {th }}$ ASEAN Summit, Manila, 29 April 2017. http://asean.org/storage/2017/04/FINALChairmans-Statement-of-30th-ASEANSummit-29-Apr-2017.pdf

Kementerian Luar Negeri Republik Indonesia. 2012. ASEAN Selayang Pandang. Jakarta: Sekretariat Direktorat Jenderal Kerjasama ASEAN Kementerian Luar Negeri.

\section{Journals}

Karaganov, Sergei. 2016. Global Challenges and Russia's Foreign Policy, 20 November 2016. Retrieved 3 January 2020. https://eng.globalaffairs.ru/articles/globa 1-challenges-and-russias-foreign-policy/

Manurung, H. 2019. Russia-China Strategic Partnership in the Indo-Pacific Region: Synergizing Greater Eurasia with Belt and Road Initiative, 2016-2018. Journal Asia Pacific Studies, Volume 3 Number 1/January-June 2019, pp. 25-42. DOI. http://dx.doi.org/10.33541/japs.v3i1.954

Manurung, H. 2018. Indonesia Menuju Poros Maritim Dunia. Prosiding Seminar Nasional Pakar 2018 Buku II. Retrieved $18 \quad$ December 2020. https://www.trijurnal.lemlit.trisakti.ac.id/ index.php/pakar/article/view/2714

Manurung, H. 2018. Indonesia and Russia Relations in Response with Changing Strategic Environment. Politica, Volume 9, Number 1, May 2018. Retrieved on $10 \quad$ January 2020. https://sdip.dpr.go.id/search/detail/categ ory/Jurnal\%20Politica/id/535

Novana, Rindu Faradisah. 2012. Kerjasama Indonesia Dengan Rusia Dalam Bidang 
Pertahanan Militer Pada Masa Pemerintahan Susilo Bambang Yudhoyono Periode 2004-2009. Jurnal Transnasional, Vol.3, No. 2, Februari 2012.

Saner, Raymond and Yiu, Lichia. 2001. International Economic Diplomacy: Mutations in Post-modern Times, Discussion Papers in Diplomacy 2001. Spencer Mauby University of Leicester.

\section{Newspapers}

Kompas. 2021. Politik Luar Negeri RI Sesuai Tantangan, 7 January 2021.

Kompas. 2020. Persaingan AS-China: Asia Tenggara Paling Terdampak, 24 July 2020.

\section{Internet}

Badan Pusat Statistik Republik Indonesia. 2020. Sensus Penduduk 2020. Retrieved 3 February 2021. https://www.bps.go.id/sp2020/

Beeson, M. 2017. What's the Point of ASEAN? Retrieved August 15, 2019 from https://asean.mgimo.ru/en/opinions/693$\mathrm{v}$-sumsky-the-manila-summit-nogrounds-to-doubt-asean-s-standing

British Petroleum. 2016. BP Statistical Review of World Energy, June 2016. http://oilproduction.net/files/especial$\mathrm{BP} / \mathrm{bp}$-statistical-review-of-worldenergy-2016-full-report.pdf

Burdzik, Tomasz. 2019. Slowly but Surely: Russia's Foreign Policy in Southeast Asia, 11 September 2019. Retrieved 3 January 2020. https://russiancouncil.ru/en/analyticsand-comments/columns/asian- kaleidoscope/slowly-but-surely-russia-sforeign-policy-in-southeast-asia

Defenseworld.net. 2018. US Pressured Indonesia To Abandon Su-35 Fighter Jet Contract With Russia, 12 March 2018. Retrieved 5 January 2021. https://www.defenseworld.net/news/221 28\#.W0Z22NIzbIX.

FOX News Channel. 2017. Russian strategic bombers fly patrol mission from Indonesia, 7 December 2017. Retrieved on 11 January 2020. http://www.foxnews.com/world/2017/12 /07/russian-strategic-bombers-fly-patrolmission-from-indonesia.html.

Globalaffairs.ru. 2016. Global Challenges and Russia's Foreign Policy, 20 November 2016. Retrieved 3 January 2020. https://eng.globalaffairs.ru/articles/globa 1-challenges-and-russias-foreign-policy/

Indonesia Ministry of Foreign Affairs. 2021. ASEAN-Russia Senior Officials Meeting (ARSOM) Ke-17: Implementasi ASEANOutlook on the Indo-Pacific Adalah Kunci untuk Pemulihan Pandemi. 27 January 2021. Retrieved 30 January 2021.

https://kemlu.go.id/portal/id/read/2104/v iew/asean-russia-senior-officialsmeeting-arsom-ke-17-implementasiasean-outlook-on-the-indo-pacificadalah-kunci-untuk-pemulihan-pandemi.

Indonesia Ministry of Foreign Affairs. 2020. Pernyataan Pers Tahunan Menteri Luar Negeri RI 2020: Prioritas Diplomasi 4+1 \#Diplomacy4PeaceandProsperity. 8 January 2020. Retrieved December 5, 2020.

https://kemlu.go.id/ankara/id/news/4152/ pernyataan-pers-tahunan-menteri-luar- 
negeri-ri-2020-prioritas-diplomasi-41-

diplomacy4peaceandprosperity

International Monetary Fund. 2016. World Economy Outlook 2016. Retrieved December 13, 2020. https://www.imf.org/en/Publications/WE O/Issues/2016/12/31/Subdued-DemandSymptoms-and-Remedies.

Kementerian Luar Negeri Republik Indonesia. 2021. Indonesia-Rusia Berkomitmen Tuntaskan Hambatan Perdagangan Kedua Negara, 3 January 2021. Direktorat Jenderal Amerika dan Eropa. Retrieved 4 January 2021. https://kemlu.go.id/portal/id/read/2218/b erita/indonesia-rusia-berkomitmentuntaskan-hambatan-perdagangankedua-negara

Kementerian Luar Negeri Republik Indonesia. 2016. Kajian Mandiri: Indonesia dan Asia Tengah: Sebuah Upaya Penguatan Diplomasi Ekonomi. Badan Pengkajian dan Pengembangan Kebijakan, Jakarta. Retrieved December 2, 2020. https://kemlu.go.id/download/L3NpdGV zL3B1c2F0L0RvY3VtZW50cy9LYWp pYW4gTWFuZGlyaSBEaXBsb21hc2kg IEVrb25vbWkgQXNpYSBUZW5nYW ggSmFudWFyaSAyMDE3LnBkZg\%3D $\% 3 \mathrm{D}$.

Kementerian Pertahanan Republik Indonesia. 2018. Kebijakan Pertahanan Negara Tahun 2018. Wira Edisi Januari-Pebruari 2018 Volume 70 Nomor 54. Retrieved 5 January 2021. https://www.kemhan.go.id/wpcontent/uploads/2018/03/wirajanfeb18website-kemhanOK.pdf.

Kementerian Pertahanan Republik Indonesia. 2017. Kebijakan Pertahanan Negara 2018. Retrieved January 10, 2021. https://www.kemhan.go.id/2018/02/14/k

ebijakan-pertahanan-negara-tahun2018.html.

Kementerian Pertahanan Republik Indonesia. 2010. Peraturan Presiden Republik Indonesia Nomor 41 Tahun 2010 Tentang Kebijakan Umum Pertahanan Negara 2010-2014. Retrieved December 10 , 2020. https://www.kemhan.go.id/strahan/2016/ 09/29/perpres-no-41-tahun-2010tentang-kebijakan-umum-pertahanannegara-tahun-20102014.html.

Коммерсанть. 2014. Запад должен пойти

навстречу России. Журнал

"Коммерсанть Власть" №11. Дата обращения 10 декабря 2020 г. https://www.kommersant.ru/doc/242259 7.

Kopylov, Oleg. 2012. ЭНЕРГЕТИЧЕСКОЕ СОТРУДНИЧЕСТВО В ИНТЕГРАЦИОННОМ КОНТЕКСТЕ ЮBА И АTP: НОВЫЕ ВОЗМОЖНОСТИ ДЛЯ РОССИИ. Retrieved January 5, 2021. https://indonesia.mid.ru//energeticeskoe-sotrudnicestvo-vintegracionnom-kontekste-uva-i-atroleg-kopylov-?

Manurung, H. 2020. Indonesia - EAEU relations: developing trade and economic cooperation. Retrieved January 5, 2021. https://miwiinstitut.de/archives/572.

Manurung, H. 2018. Mепиju Poros Maritim Dunia: Masa Depan Indonesia. Retrieved December 1, 2020. https://www.researchgate.net/publication /323369195_MENUJU_POROS_MARI TIM_DUNIA_MASA_DEPAN_INDO 
NESIA.

DOI:

10.13140/RG.2.2.35254.60489.

Manurung, H. 2012. Indonesia Economic Diplomacy Strategy, the President Post Indonesia, 12 November 2012.

Retrieved December 11, 2020 https://www.thepresidentpost.com/2012/ 11/12/indonesia-economic-diplomacystrategy.

Mordyushenko, Olga and Kozlov, Dmitry. 2016. Rosneft focuses on development in Indonesia. Kommersant May 5, 2016. Retrieved $30 \quad$ June 2020. https://www.rbth.com/economics/busine ss/2016/05/05/rosneft-focus-ondevelopment-in-indonesia_590239

Посольство Республики Индонезия в Российской Федерации и Республике Беларусь. Министр обороны Прабово встретился с министром обороны России для обсуждения расширения сотрудничества, 30 января 2020 г. Дата обращения 5 октября 2020. https://kemlu.go.id/moscow/lc/news/449 8.

Посольство Российской Федерации в Республике Индонезия. 2020.

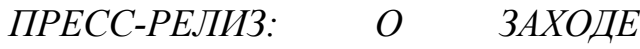
КОРАБЛЕЙ ТИХООКЕАНСКОГО ФЛОТА ВМФ РОССИИ, 18 декабря 2020 г. Retrieved 6 January 2021. https://indonesia.mid.ru/arhiv-novostej2020/-

/asset_publisher/O1EcZeZJvpd5/content /o-zahode-korablej-tihookeanskogoflota-vmf-rossii?

Посольство Российской Федерации в Республике Индонезия. 2015. Интервью Посла России в Индонезии М.Ю.Галузина информагентству «Россия сегодня», 10 февраля 2015 г.
Retrieved 3 January 2021. https://indonesia.mid.ru/posol-rossii-vindonezii-o-dvustoronnemsotrudnicestve//asset_publisher/VQ4x2Q4Lat4O/conten t/interv-u-posla-rossii-v-indonezii-m-ugaluzina-informagentstvu-rossiasegodna-?

Президент России. 2018. Саммит РоссияACEAН. Кремль , 14 ноября 2018 года. Дата обращения 3 января 2021 г. http://www.kremlin.ru/events/president/ news/59120.

Russian Foreign Policy. 2018. The Foreign policy Concept of the Russian Federation. Approved by Dmitry A. Medvedev, President of the Russian Federation, on 12 July 2008. Retrieved December 30, 2020 from https://www.indonesia.mid.ru/rus_fp_e_ 12.html

Santosa, I. Novan. 2019. Russia vows stronger ties with Indonesia, ASEAN. The Jakarta Post July 1, 2019. Retrieved December 30 , 2020. https://www.thejakartapost.com/news/20 19/07/01/russia-vows-stronger-ties-withindonesia-asean.html

TAСС. 2020. Шойгу: отношения РФ $и$ Индонезии могут выйти на уровень стратегического партнерства. TASS 28 января 2020 г. Дата обращения 30 января 2021 г . https://tass.ru/armiya-iopk/7625561.

TACС. 2018. Путин выступит на саммите Россия-АСЕАН, встретится $\mathrm{c}$ лидерами Японии и Южной Кореи. TACC 14 ноября 2018 г. Retrieved December 5, 2020. https://tass.ru/politika/5789487 
The European Parliament. The EU and Russia: Locked into confrontation. July 28, 2020. Retrieved January 3, 2021. https://www.europarl.europa.eu/thinktan $\mathrm{k} / \mathrm{en} /$ document.html?reference $=$ EPRS_B RI(2020)652030.

The National Interest. 2018. A Russian Pivot to Asia? 1 November 2018. Retrieved December 30, 2020. https://nationalinterest.org/feature/russia n-pivot-asia-34892

Utami, R.V. 2014. Rusia Dukung Indonesia jadi Poros Maritim. CNN Indonesia November 8，2014. Retrieved 30 December 2020. https://www.cnnindonesia.com/internasi onal/20141108105016-134-10391/rusiadukung-indonesia-jadi-poros-maritim

Wandelt, Ingo. 2007. Between Economic and Security Interests: Russia's Return to the Indonesian Archipelago, 3 November 2007. Retrieved December 30, 2020.

https://www.watchindonesia.org/17629/r ussias-return-to-the-indonesianarchipelago?lang=en

Warta Ekonomi. 2020. Indonesia-Rusia Tingkatkan Kerja Sama Perdagangan \& Investasi, 19 October 2020. Wartaekonomi.co.id. Retrieved January 5 , 2021. https://www.wartaekonomi.co.id/read30 9843/indonesia-rusia-tingkatkan-kerjasama-perdagangan-investasi

World Nuclear Association. 2021. Uranium and Nuclear Power in Kazakhstan, January 2021. Retrieved December 4, 2020.

https://www.worldnuclear.org/information-library/countryprofiles/countries-g-n/kazakhstan.aspx
World Nuclear Association. 2020. Uranium in Uzbekistan, February 2020. Retrieved December 5, 2020. https://www.worldnuclear.org/information-library/countryprofiles/countries-t-z/uzbekistan.aspx 